Article

\title{
Populism versus Technocracy? Populist Responses to the Technocratic Nature of the EU
}

\author{
Marion Reiser * and Jörg Hebenstreit \\ Department of Political Science, University of Jena, 07743 Jena, Germany; E-Mails: marion.reiser@uni-jena.de (M.R.), \\ joerg.hebenstreit@uni-jena.de (J.H.) \\ * Corresponding author
}

Submitted: 15 June 2020 | Accepted: 6 October 2020 | Published: 17 December 2020

\begin{abstract}
While populism and technocracy have attracted enormous scientific attention in recent years, surprisingly how the two concepts relate to each other has rarely been investigated. Looking at the case of the EU, we investigate how populist parties position themselves in relation to technocracy in general and the technocratic nature of EU institutions in particular. In a first theoretical step, we identify the core elements, modes of governance, and policy output of technocratic governance and use them to derive potential responses of populist parties. In the empirical part, we investigate these aspects of technocracy by applying quantitative and qualitative approaches using the 2019 European election manifestos of 12 populist parties. We show that left- and right-wing populist parties articulate anti-technocratic positions, particularly regarding the core elements of technocratic governance. The concrete technocratic critique differs regarding the respective host ideology. However, within the group of hybrid populist parties, ANO 2011 and GERB appear not to have a critical stance towards technocracy and thus can be classified as technocratic populist parties.
\end{abstract}

\section{Keywords}

bureaucracy; European elections; European Union; Euroscepticism; populism; regulation; technocracy

\section{Issue}

This article is part of the issue "Varieties of Technocratic Populism around the World" edited by Petra Guasti (Institute of Sociology of the Czech Academy of Sciences, Czech Republic) and Lenka Buštíková (Institute of Sociology of the Czech Academy of Sciences, Czech Republic / Arizona State University, USA).

(C) 2020 by the authors; licensee Cogitatio (Lisbon, Portugal). This article is licensed under a Creative Commons Attribution 4.0 International License (CC BY).

\section{Introduction}

It is not the French and their Marine Le Pen, not the Austrians and their Heinz-Christian Strache, not the Hungarians and their Viktor Orbán, and it is not us Germans from the AfD who are driving Europe against the wall, but it is these Brussels technocrats who do it and it is to these people that we are declaring war. (Jörg Meuthen, top candidate of the AfD for the European elections 2019 at the AfD European election campaign kick-off on 06 April 2019 in Offenburg; AfD, 2019a)

After 20 years of experience with governance by our political parties, I do not much trust the flowery claims. What I believe in...is that a state can be run like a private company, not like a chaotic juggernaut, where the godfather's right-hand does not know what the left one is doing. (Andrej Babiš of ANO 2011 in 2013, as cited in Havlík, 2019)

With the rise of both populism and technocratic governance in recent years, there has been extensive research on these two phenomena (e.g., Caramani, 2017; Mair, 2013; Mudde, 2004). Since both are perceived as symptoms of a broader crisis of democratic legitimacy and as types of 'democratic disfiguration' (Urbinati, 2014), the literature has focused on the commonalities and differences in their relation to representative democracy (e.g., Bickerton \& Invernizzi Accetti, 2017; Caramani, 
2017). However, hardly any research has explored how the two phenomena relate to each other. It is argued, that adopting a unidirectional perspective helps to better understand the specific relations between them as well as the phenomena themselves. We aim to do this by exploring the responses of populist parties to technocratic governance. The above-quoted statements of the two populist parties AfD and ANO 2011 point to different perceptions of technocracy: While Jörg Meuthen from the German right-wing populist party AfD is 'declaring war' to the Brussels technocrats, Andrej Babiš from ANO 2011 promises to 'run the state as a firm' and promotes technocracy and efficiency as the main solution for politics (Buštíková \& Guasti, 2019; Havlík, 2019). This raises questions about varieties of populist responses to technocratic governance and whether there are distinct responses depending on the type of populism. To investigate this empirically, the EU provides an ideal case since its technocratic nature is regularly and harshly criticized, it has also been noted by Habermas that the EU is in "the lure of technocracy" (Habermas, 2015, p. 3; see also Pirro, Taggart, \& van Kessel, 2018; Radaelli, 1999). Therefore, the central research question is: How do populist parties respond to technocracy and, in particular, to the technocratic nature of EU institutions and governance?

A comparative framework is proposed to analyze whether and how the populist core and the host ideology of populist parties influence the positions of the populist parties to technocracy. Therefore, we investigate populist parties' responses towards the technocratic nature of the EU through a comparison of different types of populist parties (right-wing, left-wing, hybrid [including technocratic]) based on the party manifestos for the European elections 2019. In the following, based on the central concepts, the conceptual framework and the hypotheses are developed. The third section presents data and methods, followed by the analysis and the conclusions.

\section{Theoretical Framework: Connecting Populism and Technocracy}

Despite being a contested concept, the sharp contrasting of the 'pure people' and the elite is the core characteristic of almost all definitions of populism (Mudde, 2004; Roberts, 1995). Instead of a corrupt elite, politics should be an expression of the volonté générale of the people and needs to directly communicate with the people (Urbinati, 2014, p. 132; see also Albertazzi \& McDonnell, 2008; Rooduijn, 2013). Given its nature as a 'thin-centred ideology,' populism "can be easily combined with very different (thin and full) other ideologies" (Mudde, 2004, p. 544; see also Heinisch \& Mazzoleni, 2017; Taggart, 2004). Therefore, populist parties are not only characterized by their populist element but also by their host ideology. Thus, different forms have been distinguished: as well as right-wing and left-wing populism, a third cluster is characterized by a fuzziness on the left- right spectrum and has been defined as hybrid (Bickerton \& Invernizzi Accetti, 2018), centrist (Ivaldi, 2020; Stanley, 2017), or valence populism (Zulianello, 2020). Recently, technocratic populism has been discussed as a distinct form of valence populism. Since it uses "the appeal of technical expertise to connect directly with the people" (Buštíková \& Guasti, 2019, p. 302; see also Havlík, 2019), it is of particular interest for the focus of this article.

The technocratic conception of politics suggests that political decisions are taken by unelected experts, rather than by traditional elected representatives. A transfer of authority to expertocratic institutions is believed to ensure that decisions are rational, depoliticized, and impartial (Caramani, 2017; Putnam, 1977). The EU has been characterized as the "the ultimate technocratic project" (Leonard, 2011, p. 2) because of its large number of technocratic institutions (e.g., European Central Bank, the European Court of Justice, other Independent Regulatory Agencies).

\subsection{Relating Populism and Technocracy: Commonalities and Differences}

Research has analyzed the commonalities and differences of populism and technocracy particularly in their relationship to representative and party democracy (Urbinati, 2014). By applying such a 'relational perspective,' both phenomena are perceived as symptoms of a broader crisis of democratic legitimacy that share "a unitary, nonpluralist, unmediated, and unaccountable vision of society's general interest" (Caramani, 2017, p. 54) and have party democracy as their common enemy. Thus, the two phenomena are perceived as "mirror images of each other" (Müller, 2014, p. 490). But there is also a second-diametrically opposed-perception that they are "two extreme poles of the continuum of politics" (Worsley, 1993, p. 730) because of the differences in relation to central features of representation such as legitimacy, political authority, and the role of the people.

From this perspective, technocracy and populism seem incompatible. However, surprisingly, populism and technocracy have rarely been directly connected. It is argued in this article, that adopting a 'unidirectional perspective' that looks at technocracy through populist glasses is important to better understand the specific relations between the two phenomena as well as the phenomena themselves.

\subsection{Adopting a Unidirectional Perspective: Populists' Responses to the Technocratic Character of the EU}

In order to analyze how populist parties position themselves in relation to technocracy, it has to be clarified which dimensions are relevant from a theoretical perspective. In line with the literature on technocracy (Bickerton \& Invernizzi Accetti, 2017; Caramani, 2017; Urbinati, 2014), three central dimensions can be identified and used to derive potential responses to tech- 
nocracy: (1) the core ideas, (2) the modes, and (3) the output of technocratic governance. These aspects can be addressed by both critical and approving responses. Before elaborating on these three dimensions, it has to be stressed that due to the focus on technocracy and populism other populist responses to the EU-pro-European and Eurosceptic positions-are not in the scope of this article (see Section 3 for details). Euroscepticism has been defined as the "idea of contingent or qualified opposition, as well as incorporating outright and unqualified opposition to the process of European integration" (Taggart, 1998, p. 366). The degree of opposition ranges from hard to soft Euroscepticism and comprises critique from an economic, cultural, or political perspective (Hooghe \& Marks, 2007; Taggart, 2004). Within this debate, technocratic critique has been conceptualized as an element of the political criticism of the EU. Research has revealed thatin particular right-wing-populist parties in Europe are often Eurosceptic (e.g., Harmsen, 2010; Pirro et al., 2018). However, it has been stressed that populists are not Eurosceptic per se (e.g., Kneuer, 2019). For instance, Kaniok and Havlík (2016) show that ANO 2011-despite being a populist party-has a pro-European attitude. Hence, although Euroscepticism and technocratic critique of the EU overlap, they are neither conceptually nor empirically congruent. Thus, conceptually, populist responses to technocracy can refer to the following three central dimensions.

First, responses to technocracy can refer to its core idea of a unitary, common, and objective interest of a given society. Technocratic governance implies the presence of technocratic elites, which identify the objective interest based on expertise and "rational speculation" (Caramani, 2017, p. 61). By refraining from mediation and aggregation of different conflicting interests (e.g., by political parties), depoliticized, and rational solutions to problems can be achieved. These central ideas can be positively approved by populist parties or criticized. Criticism could refer to a lack of input legitimacy due to the unelected nature of technocratic elites and institutions, as well as decisions which break the chain of delegation and lack popular sovereignty. Other arguments could refer to a lack of responsibility and control and the depoliticized nature of politics.

Second, building on these central ideas, responses can also refer to the modes of technocratic governance. While bureaucracy is a constitutive element of all forms of government, it is - together with regulationconsidered as of particular importance for a technocratic way of governing (Esmark, 2020; Majone, 2007). As Scicluna and Auer (2019) demonstrate, the monetary crisis has made the EU government more technocratic and increased the 'regulatory space.' This includes regulations of policy areas by implementing regulatory standards through expertocratic and non-majoritarian regulatory bodies such as the European Central Bank or the European Commission. Since the activities of tech- nocratic elites are described as mostly non-transparent (Radaelli, 1999, p. 155), responses are also expected from this perspective. Although technocratic institutions may appear to be less vulnerable to lobbying due to their independence from the electoral process, the danger of 'corporate' and 'regulatory capture' is nevertheless part of the standard critique of technocratic institutions (Majone, 1994, pp. 10, 21). These modes of governance can be evaluated positively as efficient and rational forms of governance, or they may be criticized from two perspectives: Either because of their lack of transparency, or their overregulation.

A third dimension of responses refers to technocratic output and policy results which are ascribed to the technocratic nature of decision-making. In relation to the EU, it is assumed that responses refer in particular to those policy areas which are increasingly tackled at the European level such as monetary and fiscal policy, economic policy, migration policy, austerity policy, and consumer protection policy. Technocratic output is open to criticism because it involves political decisions taken by democratically illegitimate, unaccountable, and nontransparent actors-or in other words, by technocratic institutions. For instance, the austerity measures adopted by the Troika could be criticized both explicitly and implicitly, for being legally binding but created without democratic legitimacy, accountability, or transparency (e.g., Barrett, Corbet, \& Larkin, 2019).

How do populist parties respond to technocracy? Do they criticize or approve of the technocratic nature of the EU? And which aspects of technocracy do they respond to? As argued, we expect a variety of populists' responses. We assume that both dimensions, the populist core and the host ideology (Akkerman, 2015; Huber \& Schimpf, 2017; Mudde, 2004), influence the responses of the populist parties to technocracy.

\subsubsection{Responses of Populist Parties Concerning the Populist Core Element}

Considering the characteristics and dimensions of technocracy, from the perspective of the populist core of the parties, there are two ideal-typical responses to technocratic political approaches.

The first response is a rejection of technocracy because of the antagonism between populism and technocracy regarding their notion of the will of the people, representation, legitimacy, and political authority (Caramani, 2017). As such, it is linked to the idea that populism "is a reaction against the growing technocratization of contemporary politics" (Bickerton \& Invernizzi Accetti, 2017, p. 336). Since technocracy is based on the rule of legal, economic, technical, or scientific experts, it resembles a clear violation of the expression of the general will of the people. Thus, while populists identify the hegemonic unity of the true people as the ultimate guideline of representation, the cutting of ties between political decision-making and the people, as 
advocated by technocracy, represents a radical departure from this standard. As a consequence of the different notion of representation, anti-technocratic populists criticize a clear lack of input legitimacy present in technocratic governance. The same should be true for political authority, which in anti-technocratic populist terms legitimately only can be derived from the will of the 'true people' and in turn explicitly cannot be legitimized on the basis of rational, impartial, and correct decisions generated by distant technocratic institutions.

In contrast to this first ideal-type reaction, a second potential response is a positive assessment of technocracy by combining populist and technocratic elements (Bickerton \& Invernizzi Accetti, 2017; Buštíková \& Guasti, 2019; de la Torre, 2013) based on the described commonalities of a unitary conception and unmediated interest of society. As such, it uses the pretext of technocratic expertise to rule in the name of the people (Müller, 2016). Such a response might also rely on the shared criticism of populism and technocracy against the current ruling political elite as well as party democracy. In contrast to the first response, it is assumed that this response does not refer to a lack of input legitimacy but rather stresses the role of the output legitimacy that could be reached if the current political elite were replaced with technocrats to transform the general will of the true people.

Since the unidirectional perspective reveals more differences than commonalities between populism and technocracy, we expect that populist parties are more likely to reject technocracy than approve it. The second response is thus expected to be rather an exceptional case. Therefore, Hypothesis 1 reads as follows:

H1: Populist parties are more likely to criticize the technocratic nature of the EU than approve of it.

\subsubsection{Responses of Populist Parties Concerning the Role of the Host Ideology}

Second, we expect considerable variation in the responses to technocracy depending on the attitudes that constitute the respective host ideologies (Akkerman, 2015; Katsambekis, 2017). In particular, we assume that the responses of the left-wing and right-wing populist parties to the modes of technocratic governance and the technocratic output will differ. Since left and right conceptions of politics vary considerably in terms of the size of the state and the extent of regulations that can aim at virtually all aspects of public life (Budge, 2013; Sartori, $1976 / 2005)$, it is to be expected that left-wing populists are open to regulation and bureaucracy. Research shows that right-wing populists are more heterogeneous: while neo-liberal populists are generally opposed to government intervention (Betz, 1993), radical right-wing populists are not necessarily opposed to these interventions (Otjes, Ivaldi, Jupskås, \& Mazzoleni, 2018). Nevertheless, we assume that averagely left-wing populist parties are less critical to regulation and bureaucracy than right- wing populist parties. Research on Euroscepticism has revealed (e.g., Pirro et al., 2018; Pirro \& van Kessel, 2017) that left-wing populist parties criticize the EU for its 'neoliberal' agenda and the austerity measures imposed by EU institutions, and their negative economic and social consequences. Accordingly, it is assumed that the response to technocracy is also particularly related to issues such as austerity policy and economic policies. In contrast, as a result of nativism being their core ideological element (Mudde, 2007), right-wing populist parties are assumed to perceive the EU as a threat to cultural homogeneity and national sovereignty (Pirro et al., 2018). In line with this, we assume that right-wing populist parties respond to technocracy particularly in relation to policy issues of migration, and border protection. Assumptions about hybrid populists who reject placing themselves on the ideological left-right spectrum are by contrast hard to formulate. Due to their chameleon-like nature, they are expected to show characteristics of both classic left- and right-wing populist actors. Due to the positive evaluation of technocracy, technocratic populists are expected to not criticize modes of governance and policy results as a result of the technocratic nature of the EU. Therefore, the Hypotheses $2 \mathrm{a}-2 \mathrm{c}$ read as follows:

H2a: Left-wing populist parties are less likely to criticize regulation and bureaucracy as technocratic modes of governance than other populist parties.

$\mathrm{H} 2 \mathrm{~b}$ : Right-wing populist parties are more likely to criticize policy results which are ascribed to the technocratic nature of decision-making in fields related to cultural issues. In contrast, left-wing populist parties are more likely to criticize policy results related to economic issues.

H2c: Technocratic populist parties are less likely to criticize technocratic modes of governance and policy results in relation to the technocratic nature of decision-making.

\section{Methods, Case Description and Data}

The empirical analysis is based on the party manifestos for the European election, 2019. The ninth election of the European Parliament took place on 23-26 May 2019, with the election campaign being dominated by economic issues such as economic growth and the fight against unemployment (Eurobarometer, 2019). While the importance of migration policy issues appears to have diminished, growing importance was attached to the issue of climate protection. According to a tally by Ivaldi (2020, pp. 77-78), in the 2019 European Parliament elections right-wing populist parties campaigned in 20 countries, left-wing populist (left-wing populist) parties in 12 countries, and hybrid populist parties in nine countries which also comprises the type of technocratic populist party (see also Rooduijn et al., 2020; Zulianello, 2020). 
In order to analyze whether there are systematic differences between these types of populist parties, we systematically selected 12 cases based on two main criteria: First, we selected for each type four parties, which were assigned to the same type in both Zulianello's (2020) and Ivaldi's (2020) classifications. Second, these parties had to cover Western Europe, Southern Europe, as well as Central and Eastern Europe. Based on these criteria, the following cases were included in the sample: DIE LINKE (Germany, left-wing populist), Podemos (Spain, left-wing populist), Syriza (Greece, left-wing populist), Levica (Slovenia, left-wing populist), M5S (Italy, hybrid populist), ANO 2011 (Czech Republic, hybrid populist), OL'aNO (Slovakia, hybrid populist), GERB (Bulgaria, hybrid populist), AfD (Germany, right-wing populist), RN (France, right-wing populist), Vox (Spain, right-wing populist), and Jobbik (Hungary, right-wing populist). Since there is no hybrid populist party in Western Europe and only one in Southern Europe (M5S; see Zulianello, 2020), three hybrid populist parties are included from Central and Eastern Europe (ANO 2011, OL'aNO, GERB). ANO 2011 has also been characterized as a technocratic populist party. The selected cases include government (e.g., ANO 2011) and opposition parties (e.g., AfD). This might be of relevance as governing parties can be expected to be less Eurosceptic since they are at least partially responsible for staff and content of European policy. Moreover, the selected parties vary regarding their position to the EU, from hard Euroscepticism (e.g., RN) to pro-European (e.g., GERB), which allows for better disentanglement of the relationship between technocracy, populism, and Euroscepticism.

Election manifestos are appropriate documents since they are "the only authoritative collective statement" (Hansen, 2008, p. 203) of parties and thus show what a party stands for at a certain point of time. They allow for cross-national studies and have been used widely to study populist parties (e.g., Manucci \& Weber, 2017; Rooduijn, de Lange, \& van der Brug, 2014). The manifestos were analyzed through a qualitative and quantitative content analysis (Mayring, 2015). The deductive content analysis is based on the central categories elaborated in Section 2.2 (see Table 1). For the qualitative analysis, it is combined with inductive logics (see Table 2). This is the most common way to measure the manifestos of populist parties (Rooduijn et al., 2014). The unit of measurement is the sentence. The scores in Table 1 represent the percentages of words for the different categories of each manifesto. Each sentence has only been assigned to one category. If a sentence contains messages of two or more categories, the sentence was assigned to the most dominant message.

During the process of coding, it was important to separate criticism of technocracy from other forms of Euroscepticism. Theoretically, statements can connect Euroscepticism and criticism of technocracy in three different combinations: A statement can be (1) Eurosceptic but not critical of technocracy, (2) Eurosceptic and crit- ical of technocracy, and (3) non-Eurosceptic and critical of technocracy. While the second and third combination are relevant, the first combination is not part of the analysis since it is not related to technocracy. Examples are critical statements about the federation principle, violations of the subsidiarity principle or doubting the competence of a member state. The option (2) combines a Eurosceptic with a technocratic-critical message and thus cannot be entirely disentangled. An example is the following statement by the AfD:

Due to a lack of a close relationship with the citizens, the intransparency of the EU institutions, their far-reaching regulatory power and their decisions on enormous financial resources, a machinery of representatives involving more than 25,000 lobbyists established in the control centers of the EU. (AfD, 2019b, p. 13)

It combines a Eurosceptic (general democratic deficit) stance with a distinctly technocratic-critical perspective. An example of the third combination is when a party has a pro-European stance but criticizes the technocratic mode of governance.

Concerning the evaluation of the technocratic nature of the EU (see Table 2), it was coded ' 0 ' if there was no statement in the manifesto. A relevant statement which criticized technocracy was labelled with a '-' (e.g., a call for "debureaucratization"; DIE LINKE, 2019, p. 28). If the intensity and tonality of the criticism were extreme, the code '- -' was assigned (e.g., demands for a "shrinkage of the inflated bureaucratic apparatus"; AfD, 2019b, p. 12). The same principle was applied for positive responses to technocracy. To assess inter-coder reliability, all manifestos were coded by both authors. The percentage agreement and Cohen's Kappa are almost perfectly consistent (Landis \& Koch, 1977).

\section{Empirical Evidence}

As a first step of the data analysis, we analyze whether and to which extent the different populist parties respond to the technocratic nature of the EU in the electoral manifestos (Table 1). Notably, every election manifesto contains elements of responses to technocratic governance, though the share varies considerably between $0.2 \%$ and $27.2 \%$. In particular, the manifestos of M5S (22.6\%) and RN (27.2\%) contain very high levels of reactions to the technocratic governance of the EU. For the other parties, with an average value of $5.7 \%$ and a range between $0.2 \%$ and $7.5 \%$, technocratic responses are less dominant. Nevertheless, this share of technocracyrelated messages is of a similar level as the share of populist messages of populist parties in their manifestos: For example, the study of Rooduijn et al. (2014) reveals that an average of $7.4 \%$ of the paragraphs of the election manifestos of populist parties contained populist messages (ranging between $1.0 \%$ and $23.1 \%$ ). This points to 
COGITATIO

Table 1. Share of populist parties' responses to the technocratic nature of the EU.

\begin{tabular}{|c|c|c|c|c|c|c|c|c|c|c|c|c|c|}
\hline \multirow{2}{*}{$\begin{array}{l}\text { Type of } \\
\text { Populist Party } \\
\text { Response to } \\
\text { Technocratic } \\
\text { Governance of } \\
\text { the EU }\end{array}$} & \multirow[b]{2}{*}{ Dimension } & \multicolumn{4}{|c|}{ Left-Wing Populist } & \multicolumn{4}{|c|}{ Hybrid Populist } & \multicolumn{4}{|c|}{ Right-Wing Populist } \\
\hline & & $\begin{array}{l}\text { DIE LINKE } \\
\text { GERMANY }\end{array}$ & $\begin{array}{l}\text { Podemos } \\
\text { SPAIN }\end{array}$ & $\begin{array}{l}\text { Syriza } \\
\text { GREECE }\end{array}$ & $\begin{array}{l}\text { Levica } \\
\text { SLOVENIA }\end{array}$ & $\begin{array}{l}\text { M5S } \\
\text { ITALY }\end{array}$ & $\begin{array}{c}\text { ANO } 2011 \\
\text { CZECH REPUBL. }\end{array}$ & $\begin{array}{l}\text { OL'aNO } \\
\text { SLOVAKIA }\end{array}$ & $\begin{array}{c}\text { GERB } \\
\text { BULGARIA }\end{array}$ & $\begin{array}{c}\text { AfD } \\
\text { GERMANY }\end{array}$ & $\begin{array}{c}\text { RN } \\
\text { FRANCE }\end{array}$ & $\begin{array}{l}\text { Vox } \\
\text { SPAIN }\end{array}$ & $\begin{array}{l}\text { Jobbik } \\
\text { HUNGARY }\end{array}$ \\
\hline \multirow[t]{5}{*}{ Core Features } & Input Legitimacy & $1.33 \%$ & $0.66 \%$ & - & $1.14 \%$ & - & - & - & - & $0.84 \%$ & $3.16 \%$ & $0.49 \%$ & - \\
\hline & $\begin{array}{l}\text { Control and } \\
\text { Accountability }\end{array}$ & $0.26 \%$ & $0.81 \%$ & - & $0.39 \%$ & - & - & - & - & $0.17 \%$ & $4.91 \%$ & - & $1.17 \%$ \\
\hline & Representation & $0.22 \%$ & $0.46 \%$ & - & - & $4.0 \%$ & - & - & - & - & $2.4 \%$ & - & - \\
\hline & Elites & - & $0.77 \%$ & $4.15 \%$ & - & - & - & - & - & - & $3.91 \%$ & $2.96 \%$ & $0.58 \%$ \\
\hline & $\begin{array}{l}\text { Response to Core } \\
\text { Features }\end{array}$ & $1.81 \%$ & $2.70 \%$ & $4.15 \%$ & $1.53 \%$ & $4.0 \%$ & $0.0 \%$ & $0.0 \%$ & $0.0 \%$ & $1.01 \%$ & $14.38 \%$ & $3.45 \%$ & $1.75 \%$ \\
\hline \multirow{5}{*}{$\begin{array}{l}\text { Modes of } \\
\text { Governance }\end{array}$} & Regulation & - & $0.07 \%$ & - & - & $7.62 \%$ & $2.8 \%$ & - & - & $1.21 \%$ & $2.53 \%$ & $0.87 \%$ & - \\
\hline & Bureaucracy & $0.13 \%$ & $0.53 \%$ & - & - & $3.81 \%$ & $1.0 \%$ & $5.43 \%$ & $0.22 \%$ & $1.81 \%$ & $2.96 \%$ & $0.12 \%$ & $1.29 \%$ \\
\hline & Transparency & $0.44 \%$ & $1.4 \%$ & - & $0.63 \%$ & - & - & $3.18 \%$ & - & $0.8 \%$ & - & - & $1.37 \%$ \\
\hline & $\begin{array}{l}\text { Role of Corporate \& } \\
\text { Interest Groups }\end{array}$ & $0.97 \%$ & $1.22 \%$ & - & $0.81 \%$ & - & - & - & - & $0.57 \%$ & $1.82 \%$ & $0.25 \%$ & - \\
\hline & $\begin{array}{l}\text { Responses to Modes } \\
\text { of Governances }\end{array}$ & $1.54 \%$ & $3.22 \%$ & $0.0 \%$ & $1.44 \%$ & $11.43 \%$ & $3.8 \%$ & $8.61 \%$ & $0.22 \%$ & $4.39 \%$ & $7.31 \%$ & $1.24 \%$ & $2.66 \%$ \\
\hline \multirow[t]{4}{*}{ Output } & Economic & $1.81 \%$ & $0.92 \%$ & $3.18 \%$ & $0.86 \%$ & $7.14 \%$ & - & - & - & $1.16 \%$ & $4.6 \%$ & $0.44 \%$ & $1.71 \%$ \\
\hline & Cultural & - & - & - & - & - & - & - & - & $0.23 \%$ & $0.93 \%$ & - & - \\
\hline & Other & $0.52 \%$ & $0.2 \%$ & - & - & - & - & - & - & $0.74 \%$ & - & $0.84 \%$ & - \\
\hline & $\begin{array}{l}\text { Responses to } \\
\text { Technocratic Output }\end{array}$ & $2.33 \%$ & $1.12 \%$ & $3.18 \%$ & $0.86 \%$ & $7.14 \%$ & $0.0 \%$ & $0.0 \%$ & $0.0 \%$ & $2.13 \%$ & $5.53 \%$ & $1.28 \%$ & $1.71 \%$ \\
\hline $\begin{array}{l}\text { Responses to } \\
\text { Technocracy }\end{array}$ & & $5.6 \%$ & $7.0 \%$ & $7.3 \%$ & $3.8 \%$ & $22.6 \%$ & $3.8 \%$ & $8.6 \%$ & $0.22 \%$ & $7.5 \%$ & $27.2 \%$ & $7.1 \%$ & $6.11 \%$ \\
\hline
\end{tabular}


Table 2. Evaluation of the technocratic nature of the EU by populist parties.

\begin{tabular}{|c|c|c|c|c|c|c|c|c|c|c|c|c|c|}
\hline \multirow{2}{*}{$\begin{array}{l}\text { Type of } \\
\text { Populist Party } \\
\text { Response to } \\
\text { Technocratic } \\
\text { Governance of } \\
\text { the EU }\end{array}$} & \multirow[b]{2}{*}{ Dimension } & \multicolumn{4}{|c|}{ Left-Wing Populist } & \multicolumn{4}{|c|}{ Hybrid Populist } & \multicolumn{4}{|c|}{ Right-Wing Populist } \\
\hline & & $\begin{array}{l}\text { DIE LINKE } \\
\text { GERMANY }\end{array}$ & $\begin{array}{l}\text { Podemos } \\
\text { SPAIN }\end{array}$ & $\begin{array}{l}\text { Syriza } \\
\text { GREECE }\end{array}$ & $\begin{array}{l}\text { Levica } \\
\text { SLOVENIA }\end{array}$ & $\begin{array}{l}\text { M5S } \\
\text { ITALY }\end{array}$ & $\begin{array}{c}\text { ANO } 2011 \\
\text { CZECH REPUBLIC }\end{array}$ & $\begin{array}{l}\text { OL'aNO } \\
\text { SLOVAKIA }\end{array}$ & $\begin{array}{c}\text { GERB } \\
\text { BULGARIA }\end{array}$ & $\begin{array}{c}\text { AfD } \\
\text { GERMANY }\end{array}$ & $\begin{array}{c}\text { RN } \\
\text { FRANCE }\end{array}$ & $\begin{array}{l}\text { Vox } \\
\text { SPAIN }\end{array}$ & $\begin{array}{l}\text { Jobbik } \\
\text { HUNGARY }\end{array}$ \\
\hline \multirow[t]{5}{*}{ Core Features } & Input Legitimacy & -- & -- & 0 & -- & 0 & 0 & 0 & 0 & -- & -- & - & 0 \\
\hline & $\begin{array}{l}\text { Control and } \\
\text { Accountability }\end{array}$ & - & -- & 0 & - & 0 & 0 & 0 & 0 & - & - & 0 & - \\
\hline & Representation & - & -- & 0 & 0 & - & 0 & 0 & 0 & 0 & -- & 0 & 0 \\
\hline & Elites & 0 & -- & -- & 0 & 0 & 0 & 0 & 0 & 0 & -- & -- & - \\
\hline & $\Sigma$ & - & -- & - & - & - & 0 & 0 & 0 & - & -- & - & - \\
\hline \multirow{5}{*}{$\begin{array}{l}\text { Modes of } \\
\text { Governance }\end{array}$} & Regulation & 0 & - & 0 & 0 & ++ & - & 0 & 0 & -- & -- & -- & 0 \\
\hline & Bureaucracy & - & - & 0 & 0 & - & - & - & - & -- & -- & - & -- \\
\hline & Transparency & -- & -- & 0 & - & 0 & 0 & - & 0 & - & 0 & 0 & - \\
\hline & $\begin{array}{l}\text { Role of Corporate \& } \\
\text { Interest Groups }\end{array}$ & -- & -- & 0 & - & 0 & 0 & 0 & 0 & - & - & - & 0 \\
\hline & $\Sigma$ & -- & -- & 0 & - & $+\&-$ & - & 0 & - & -- & -- & - & - \\
\hline \multirow[t]{4}{*}{ Output } & Economic & -- & -- & - & -- & - & 0 & 0 & 0 & -- & - & - & - \\
\hline & Cultural & 0 & 0 & 0 & 0 & 0 & 0 & 0 & 0 & - & - & 0 & 0 \\
\hline & Other & - & - & 0 & 0 & 0 & 0 & 0 & 0 & - & 0 & - & 0 \\
\hline & $\Sigma$ & - & - & - & - & - & 0 & 0 & 0 & - & - & - & - \\
\hline
\end{tabular}

Notes: $++=$ very positive $+=$ positive $0=$ no reference $-=$ negative $;--=$ very negative . 
a high importance of populists' responses to the technocratic nature of the EU. The analyses of the parties' positions to the core ideas of technocratic governance reveal a clear pattern regarding the types of populist parties: All examined left- and right-wing populist parties criticize central core features of technocratic government. In contrast, among the hybrid populist parties, this is only true for the Italian M5S, while ANO 2011, OL'aNO, and GERB neither criticize a lack of input legitimacy, missing accountability, nor the existence of technocratic elites. Overall, one-half of the parties examined criticize the lack of input legitimacy and thus the insufficient integration of the 'general will of the people' due to the technocratic nature of EU governance. The AfD (2019b, p. 7), for example, states "that, without the consent of the citizens, an artificial state far removed from the citizens is being created." Similarly, the RN (2019, pp. 4, 17) declares that "the power should be given back to the people by abolishing the European Commission" since the 28 commissioners "were not chosen democratically." Yet, this kind of criticism is not exclusive to right-wing populists; left-wing populist parties such as Podemos $(2019$, p. 9) also criticize a "breach of legitimacy" and admonish that the "EU Parliament is inferior to bodies with little democratic legitimacy such as the Council and the Commission." DIE LINKE $(2019$, pp. 8,27$)$ points to the "undemocratic orientation of the European Central Bank and the Troika." In the same way, the Slovenian Levica $(2019$, p. 13) finds fault with "the unelected technocrats [who] have no right to write our future." Moreover, six parties also see a lack of democratic control and accountability due to technocracy. In their view, the "technocratic bodies [are] beyond" (Levica, 2019, p. 9) or "far removed" (Podemos, 2019 , p. 9) from any principle of democratic control while this important aspect in the context of EU governance is generally "totally inadequate" (AfD, 2019b, p. 11).

In addition, five parties stress the technocratic nature of the elites and thus combine the populist core element of anti-elitism with criticism of technocracy. Similar to Syriza and Vox, the RN's election manifesto repeatedly mentions so-called Eurocrats, i.e., a combination of the words 'Europe' and 'technocrats'/'bureaucrats.' In principle, the term contains three dimensions of populist criticism: In addition to a Eurosceptic attitude, the term also rejects the technocratic style of government, and finally criticizes a particular elite, namely the 'Eurocrats.' Similarly, Jobbik (2019, p. 5) states that "[t]he bureaucratic elite of the EU does nothing to solve our common European problems." The word 'technocracy' itself appears verbatim with a negative connotation in the manifestos of AfD, Levica, OL'aNO, Podemos, and RN. Referring to both quantity and quality of critique, these five parties give significantly more weight to technocratic critique compared to the others, in particular Syriza and M5S, which criticize only one or few core elements of technocracy. Despite these quantitative differences, all these populist parties share the view that technocracy is in clear opposition to the idea of the general will of the people. As mentioned above, the parties ANO 2011, OL'aNO and GERB clearly deviate from the technocratic critique of the right- and left-wing populist parties since no single element of criticism to the core features of technocratic governance can be found in their European election manifestos. In sum, based on the observed cases, being against the technocratic nature of the EU seems to be the default position of left- and right-wing populist parties. Since, numerically speaking, $75 \%$ (or 9 out of 12) of the parties investigated respond negatively to the core features of technocratic governance, there is evidence for the first hypothesis. However, the results for the three hybrid populist parties from Central and Eastern Europe, OL'aNO, GERB, and ANO 2011, clearly deviate due to their neutral or even positive stance towards technocracy. This corresponds with the findings of Buštíková and Guasti (2019) and Havlík (2019) which classified ANO 2011 as a technocratic populist party.

All examined populist parties-independent of their host ideology-criticize modes of technocratic governance. However, patterns, extent, as well as the political style of the messages differ substantially. The right-wing populist parties are significantly more critical towards regulation and-to a lesser extent-towards bureaucracy of the EU than left-wing populist parties. For instance, RN (2019, p. 5) blames the European Commission for an "irresponsible inflation of rules, constraints, and standards," and Vox (2019, p. 22) asserts that "European over-regulation and bureaucracy have ended up dynamiting innovative projects." The AfD (2019b, pp. 43, 11) refers to an "excessive bureaucracy" and demonizes a "European frenzy of regulation." Moreover, Jobbik (p. 7) criticizes the "unshakable bloc of power represented by the bureaucracy of the EU." Although left-wing-populist parties also criticize modes of technocratic governance, they do it to a lesser extent and also less aggressively. For instance, DIE LINKE $(2019$, p. 28) states that the party "advocates debureaucratization." These differences in the extent and tonality of criticism can presumably be explained by their respective host ideologies. Another striking observation is that all four hybrid populist parties studied criticize aspects of bureaucracy. An example of this observation is the Slovakian party OL'aNO, which advocates a "substantial reduction of bureaucracy" (OL'aNO, 2019, p. 2). With regard to transparency and the danger of "interest group capture," no substantial differences can be identified between left and right-wing populists. However, it is interesting to note that-with the exception of OL'aNO-the hybrid or technocratic populists do not criticize these dimensions. With regard to transparency, the cases of ANO 2011 and GERB also tell a similar story. Overall, there is some evidence for $\mathrm{H} 2 \mathrm{a}$, even though the differences in terms of bureaucracy and regulation between left-wing and right-wing populist parties are rather marginal.

With regard to policy output, the analysis reveals that right-wing populist parties criticize particularly the technocratic nature and output in the field of monetary and 
currency policy (banking union, Euro-ethics). For example, the AfD (2019b, p. 8) condemns the "banking union with the communitarization of unlimited liabilities and assistance." Left-wing populist criticism is instead directed in particular at problems that arise in the field of austerity and neoliberal economic policy. For instance, DIE LINKE (2019, p. 25) states that "the European Crisis policy of the Troika...under the leadership of the German government has plunged millions into misery." In a similar vein, Levica (2019, p. 12) states that "restricting democratic decision-making with the aim of imposing neoliberal policies is a key reason for the spread of anger, frustration and hopelessness across Europe, which encourages the growth of the far right." Criticism of particular policy output is often accompanied by a criticism of technocratic elites. For example, Syriza (2019, p. 3) argues, in the context of austerity policy, "that the ruling European elite wanted to teach the Greeks a lesson." Overall, the qualitative analysis reveals that criticism in relation to policy output is-in contrast to the other two dimensions-hardly explicit but in most cases only implicitly linked to technocracy in the manifestos, for instance by referring to the technocratic institutions, modes of governance, or the "bureaucratic elite" (Jobbik, 2019 , p. 5). On the one side, it could be argued that these statements are rather examples of Euroscepticism and anti-elitism but not for technocracy-related critique. But on the other side, it could also be argued that the output is also criticized because political decisions have been taken by technocratic institutions which are perceived as undemocratic actors. Hence, there is some evidence for criticism of policy output, which is indirectly ascribed to the technocratic nature of decision-making. However, both left- and right-wing populist parties link this predominantly to economic policies. While rightwing populist parties focus on monetary and fiscal policy, those on the left-wing refer to austerity policies. Criticisms of the EU for cultural reasons, in particular in the fields of immigration policy and border protection, are important statements in the manifestos of the (right-wing) populist parties. However, interestingly, criticism in these policy fields is not linked to technocracy. Therefore, $\mathrm{H} 2 \mathrm{~b}$ has to be rejected. In contrast, $\mathrm{H} 2 \mathrm{c}$ is confirmed since ANO 2011 and GERB as the two technocratic populist parties in the sample criticize neither the modes of technocratic governance nor policy results in relation to the technocratic nature of decision-making (ANO 2011, 2019; GERB, 2019).

\section{Conclusion}

The central research question has been how populist parties react to technocracy in general and to the technocratic nature of the EU in particular. In contrast to the relational perceptive in the existing literature, we have argued that a unidirectional perspective is required to unbox the relation between populism and technocracy. The quantitative and qualitative analyses of the
European election manifestos of 12 populist parties show that the default stance of European left- and right-wing populist parties is anti-technocratic. As such, it is not the commonalities between populism and technocracy, such as a unitary, non-pluralist, and unmediated approach of politics (Caramani, 2017) that are relevant for populist responses to technocracy. Instead, as a general rule, leftand right-wing populist parties criticize the core elements of technocracy because of the antagonism between populism and technocracy regarding their notion of the will of the people, representation, and legitimacy. In particular, technocracy is criticized because it cuts the ties between political decision-making and the people.

With regard to the category of hybrid populist parties, the picture is more complex. ANO 2011 and GERB are populist parties which do not have a critical stance towards technocracy. This result underlines the existing analyses by Buštíková and Guasti (2019) and Havlík (2019) who classified ANO 2011 as a technocratic populist party. Our results likewise give reason to interpret technocratic populism as a distinct type of populism that is significantly different from left- and right-wing, but at the same time from other hybrid forms of populism. To put it another way: ANO 2011 and GERB should therefore be classified as technocratic populist parties. In contrast, there are two hybrid populist parties in our sample, M5S and OL'aNO, which can-if at all-only partially be classified as technocratic populist. Although both parties are modest (M5S) in their criticism regarding the core features and the output of technocratic governance, or even entirely refrain from it (OL'aNO), the manifestos nevertheless clearly contain anti-technocratic stances: M5S (2019, p. 1) demands 'more power for citizens' representatives, less for bureaucrats" while OL'aNO $(2019$, p. 2) states that "[t]he technocratic mentality that prevails in Brussels, Strasbourg and Luxembourg is leading to an increase in the sense of distance between European officials and those they are meant to serve-European citizens." Accordingly, the results for OL'aNO are conceptually and empirically highly relevant for this article: the Slovakian party is not considered to be Eurosceptic (Rooduijn et al., 2020) but criticizes the technocratic nature of EU governance. Consequently, non-Eurosceptic populist parties can indeed be anti-technocratic. This supports our argument that Euroscepticism and technocratic criticism are distinct phenomena, even though they may overlap.

In addition, our analyses have shown that the technocratic critique differs with regard to the respective host ideology of the populist parties: Right-wing populist parties tend to criticize bureaucracy and regulation as modes of technocratic governance more harshly than left-wing populists which is in line with the general stances of their host ideologies. There is also some evidence for criticism of policy output which is ascribed to the technocratic nature of decision-making, but this is less explicitly articulated in the manifestos. In contrast to the results of the existing literature which suggests 
that left-wing populist parties tend to criticize the EU for economic reasons, whereas the right-wing do so for cultural reasons (Otjes et al., 2018; Pirro et al., 2018), our analyses identify technocratic critique from both types of populist parties predominantly in relation to economic policies. While right-wing populist parties focus on monetary and fiscal policy, left-wing populist parties more frequently refer to austerity policies. Criticisms of the EU for cultural reasons, in particular in the fields of immigration policy and border protection, are an important part of the manifestos, in particular of the right-wing populist parties. However, it is interesting to note that criticisms in these policy fields are not linked to technocracy.

Overall, this study has shown that the relation between populism and technocracy is also crucial to be able to understand the phenomena themselves. However, further analyses are needed to improve our understanding of their relationship. It is assumed that the responses of populist parties to technocracy at the level of the EU are partly linked to a general Eurosceptic stance of these parties. This makes it difficult to disentangle criticism of the technocratic nature of the EU from other forms of Euroscepticism. Moreover, it is possible that populist parties may criticize or reject the technocratic nature of European institutions simply for strategic reasons (Weyland, 2017). For example, it is conceivable that the EU per se could be portrayed as a scapegoat and that the supranational level, in general, might be used as a sort of lightning rod. In this respect, the rejection of technocratic EU institutions would be based on strategic motives, while populist actors might not have substantive problems with technocratic solutions. These aspects make it difficult to entirely disentangle the complex relationship between populism, technocracy, and Euroscepticism. Therefore, further studies should investigate the national level in European countries but also other regions. Another aspect of relevance is the distinction between government and opposition populist parties. Since ANO 2011 and GERB make up the governments of their countries, future research needs to address the question of whether there is a causal link between a lack of technocratic critique and the takeover of government offices. In addition, future studies should also include non-populist parties and their attitudes towards technocratic solutions and compare them with those of populist parties. This would allow the analysis of whether criticism of technocracy is stronger among populist parties than among other parties and thus if populism drives criticism of technocracy.

\section{Acknowledgments}

The authors would like to thank the research assistants Mathis Brinkmann, Volker Brandy, and Johannes Weiß as well as the Academic Editors and anonymous referees who kindly reviewed the manuscript and provided valuable comments. The authors contributed equally (reversed alphabetical order).

\section{Conflict of Interests}

The authors declare no conflict of interests.

\section{References}

Akkerman, T. (2015). Immigration policy and electoral competition in Western Europe. Party Politics, 21(1), 54-67.

Albertazzi, D., \& McDonnell, D. (Eds.). (2008). Twentyfirst century populism: The spectre of Western European democracy. Basingstoke: Palgrave.

AfD. (2019a). AfD-Wahlauftakt für ein Europa der Vaterländer und der Vielfalt [AfD election kick-off for a Europe of fatherlands and diversity]. AfD Kompakt. Retrieved from https://afdkompakt.de/2019/04/06/ afd-wahlauftakt-fuer-ein-europa-der-vaterlaenderund-der-vielfalt

AfD. (2019b). Europawahlprogramm-Programm der Alternative für Deutschland für die Wahl zum 9. Europäischen Parlament 2019 [European election manifesto-Manifesto of the Alternative for Germany for the election to the 9th European Parliament in 2019]. Berlin: Alternative für Deutschland. Retrieved from https://cdn.afd.tools/ wp-content/uploads/sites/111/2019/02/AfD_ Europawahlprogramm_A5-hoch_RZ.pdf

ANO 2011. (2019). Program hnutí ANO pro volby do Evropského parlamentu [ANO movement program for elections to the European Parliament]. ANO. Retrieved from https://www.anobudelip.cz/ file/edee/ke-stazeni/ano-cesko-ochranime.pdf

Barrett, S., Corbet, S., \& Larkin, C. (2019). Sustainability, accountability and democracy: Ireland's Troika experience. Finance Research Letters, 28(3), 53-60.

Betz, H. G. (1993). The two faces of radical right-wing populism in Western Europe. The Review of Politics, 663-685.

Bickerton, C. J., \& Invernizzi Accetti, C. (2017). Populism and technocracy. In C. Rovira Kaltwasser, P. A. Taggart, P. Ochoa Espejo, \& P. Ostiguy (Eds.), The Oxford handbook of populism (pp. 326-431). Oxford and New York, NY: Oxford University Press.

Bickerton, C. J., \& Invernizzi Accetti, C. (2018). "Technopopulism" as a new party family: The case of the Five Star Movement and Podemos. Contemporary Italian Politics, 10(2), 132-150.

Budge, I. (2013). The standard right-left scale. Berlin: WZB. Retrieved from https://manifestoproject.wzb. eu/down/papers/budge_right-left-scale.pdf

Buštíková, L., \& Guasti, P. (2019). The state as a firm: Understanding the autocratic roots of technocratic populism. East European Politics and Societies, 33(2), 302-330.

Caramani, D. (2017). Will vs. reason: The populist and technocratic forms of political representation and their critique to party government. American Political Science Review, 111(1), 54-67. 
de la Torre, C. (2013). Latin America's authoritarian drift: Technocratic populism in Ecuador. Journal of Democracy, 24(3), 33-46.

DIE LINKE. (2019). Für ein solidarisches Europa der Millionen, gegen eine Europäische Union der Millionäre [For a solidarity-based Europe of millions, against a European Union of millionaires]. Berlin: DIE LINKE. Retrieved from https://www.die-linke.de/ fileadmin/download/wahlen2019/wahlprogramm_ pdf/Europawahlprogramm_2019_-_Partei_DIE_ LINKE.pdf

Esmark, A. (2020). The new technocracy. Bristol: Bristol University Press.

Eurobarometer. (2019). Näher an den Bürgern, Näher vor der Wahl [Closer to the citizens, closer before the election]. Brussels: European Parliament. Retrieved from https://www.europarl.europa.eu/at-yourservice/de/be-heard/eurobarometer/closer-to-thecitizens-closer-to-the-ballot

GERB. (2019). Политически програми на ПП ГЕРБ [Platform for European elections - 2019]. GERB. Retrieved from http://www.gerb.bg/bg/pages/ otcheti-za-predizborni-kampanii-88.html

Habermas, J. (2015). The lure of technocracy. Cambridge and Malden, MA: Polity Press.

Hansen, M. E. (2008). Back to the archives? A critique of the Danish part of the Manifesto dataset. Scandinavian Political Studies, 31(2), 201-216.

Harmsen, R. (2010). Concluding comment: On understanding the relationship between populism and Euroscepticism. Perspectives on European Politics and Society, 11(3), 333-341.

Havlík, V. (2019). Technocratic populism and political illiberalism in Central Europe. Problems of PostCommunism, 66(6), 1-16.

Heinisch, R. C., \& Mazzoleni, O. (2017). Analysing and explaining populism: Bringing frame, actor, and context back in. In R. C. Heinisch, C. Holtz-Bacha, \& O. Mazzoleni (Eds.), Political populism. A handbook (pp. 105-122). Baden-Baden: Nomos.

Hooghe, L., \& Marks, G. (2007). Sources of Euroscepticism. Acta Politica, 42(2/3), 119-127.

Huber, R. A., \& Schimpf, C. H. (2017). On the distinct effects of left-wing and right-wing populism on democratic quality. Politics and Governance, 5(4), 146-165.

Ivaldi, G. (2020). Populist voting in the 2019 European elections. Totalitarismus und Demokratie, 17(1), 67-96.

Jobbik. (2019). Biztonságos Európát, Szabad Magyarorszagot [A Secure Europe, a Free Hungary]. Budapest: Jobbik. Retrieved from https://blob. jobbik.hu/programs/biztonsagos_europat_szabad_ magyarorszagot.pdf

Kaniok, P., \& Havlík, V. (2016). Populism and Euroscepticism in the Czech Republic: Meeting friends or passing by? Romanian Journal of European Affairs, 16(2), 20-35.
Katsambekis, G. (2017). The populist surge in postdemocratic times: Theoretical and political challenges. The Political Quarterly, 88(2), 202-210.

Kneuer, M. (2019). The tandem of populism and Euroscepticism: A comparative perspective in the light of the European crises. Contemporary Social Science, 14(1), 26-42.

Landis, J., \& Koch, G. (1977). The measurement of observer agreement for categorical data. Biometrics, 33(1), 159-174.

Leonard, M. (2011). Four scenarios for the reinvention of Europe (Essay No. 43). London: European Council on Foreign Relations.

Levica. (2019). Za Evropo ljudi, ne kapitala [For a Europe of People, not Capital]. Ljubljana: Levica. Retrieved from http://www.levica.si/wp-content/uploads/ 2019/04/Za-Evropo-ljudi-ne-kapitala-program-zaevropske-volitve-2019.pdf

Mair, P. (2013). Ruling the void: The hollowing of Western democracy. London: Verso.

Majone, G. (1994). Independence vs. accountability? Non-majoritarian institutions and democratic government in Europe (Working Paper No. 94/3). Florence: European University Institute.

Majone, G. (2007). The rise of the regulatory state in Europe. West European Politics, 17(3), 77-101.

Manucci, L., \& Weber, E. (2017). Why the big picture matters: Political and media populism in Western Europe since the 1970s. Swiss Political Science Review, 23(4), 313-334.

Mayring, P. (2015). Qualitative Inhaltsanalyse: Grundlagen und Techniken [Qualitative content analysis: Basics and techniques]. Munich: Beltz.

M5S. (2019). Nuova Europa: Più democrazia diretta e stop privilegi [New Europe: More direct democracy and no more privileges]. Retrieved from https://www.cnos-scuola.it/sites/default/files/ Scheda_programma.pdf

Mudde, C. (2004). The populist zeitgeist. Government and Opposition, 39(4), 541-563.

Mudde, C. (2007). Populist radical right parties in Europe. Cambridge: Cambridge University Press.

Müller, J.-W. (2014). "The people must be extracted from within the people": Reflections on populism. Constellations, 21(4), 483-493.

Müller, J.-W. (2016). What is populism? Philadelphia, PA: University of Pennsylvania Press.

OL’aNO. (2019). Slovensko v prosperujúcej a bezpečnej Európe [Slovakia in a prosperous and secure Europe].

Dušan Šándor. Retrieved from https://dusansandor.sk/ program-hnutia-obycajni-ludia-a-nezavisleosobnosti-do-volieb-europskeho-parlamentu

Otjes, S., Ivaldi, G., Jupskås, A. R., \& Mazzoleni, O. (2018). It's not economic interventionism, stupid! Reassessing the political economy of radical right-wing populist parties. Swiss Political Science Review, 24(3), 270-290.

Pirro, A. L. P., Taggart, P., \& van Kessel, S. (2018). The pop- 
ulist politics of Euroscepticism in times of crisis: Comparative conclusions. Politics, 38(3), 378-390.

Pirro, A. L. P., \& van Kessel, S. (2017). United in opposition? The populist radical right's EU-pessimism in times of crisis. Journal of European Integration, 39(4), 405-420.

Podemos. (2019). Programa de Podemos para una Europa con más democracia, derechos, justicia y futuro [Podemos program for a Europe with more democracy, rights, justice and a future]. Madrid: Podemos. Retrieved from https://podemos.info/ wp-content/uploads/2019/05/Programa_completo_ europeas_Podemos.pdf

Putnam, R. D. (1977). Elite transformation in advanced industrial societies: An empirical assessment of the theory of technocracy. Comparative Political Studies, 10(3), 383-412.

Radaelli, C. M. (1999). Technocracy in the European Union. London and New York, NY: Routledge.

RN. (2019). Pour une Europe des nations et des peuples [For a Europe of nations and peoples]. Nanterre: Rassemblement National. Retrieved from https://rassemblement-national79.fr/wp-content/ uploads/2019/04/europeennes-projet.pdf

Roberts, K. (1995). Neoliberalism and the transformation of populism in Latin America: The Peruvian case. World Politics, 48(1), 82-116.

Rooduijn, M. (2013). A populist Zeitgeist? The impact of populism on parties, media, and the public in Western Europe. Amsterdam: Universiteit van Amsterdam.

Rooduijn, M., de Lange, S., \& van der Brug, W. (2014). A populist zeitgeist? Programmatic contagion by populist parties in Western Europe. Party Politics, 20(4), 563-575.

Rooduijn, M., van Kessel, S., Froio, C., Pirro, A. L. P., de Lange, S., Halikiopoulou, D., . . . Taggart, P. (2020). The populist: An overview of populist, far right, far left, and Eurosceptic parties in Europe. Popu-list. Retrieved from www.popu-list.org

Sartori, G. (2005). Parties and party systems: A framework for analysis. Colchester: ECPR Press. (Original work published 1976)
Scicluna, N., \& Auer, S. (2019). From the rule of law to the rule of rules: Technocracy and the crisis of EU governance. West European Politics, 42(7), 1420-1442.

Stanley, B. (2017). Populism in Central and Eastern Europe. In C. Rovira Kaltwasser, P. A. Taggart, P. Ochoa Espejo, \& P. Ostiguy (Eds.), The Oxford handbook of populism (pp. 140-160). Oxford and New York, NY: Oxford University Press.

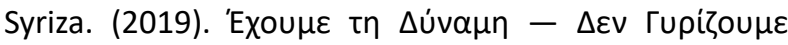
níow [We Have the Power - We Are Not Going Back]. Syriza. Retrieved from https://www.syriza.gr/ article/id/80838/Echoyme-th-Dynamh- $\bigvee-\bigvee-D e n-$ Gyrizoyme-Pisw.html

Taggart, P. (1998). A touchstone of dissent: Euroscepticism in contemporary Western European party systems. European Journal of Political Research, 33(3), 363-388.

Taggart, P. (2004). Populism and representative politics in contemporary Europe. Journal of Political Ideologies, 9(3), 269-288.

Urbinati, N. (2014). Democracy disfigured: Opinion, truth and the people. Cambridge, MA and London: Harvard University Press.

Vox. (2019). Programa electoral para las elecciones europeas de 2019 [Electoral manifesto for the 2019 European elections]. Madrid: Vox. Retrieved from https://www.voxespana.es/wp-content/uploads/ 2019/05/Programa-Europeas-2019_web.pdf

Weyland, K. (2017). Populism: A political-strategic approach. In C. Rovira Kaltwasser, P. A. Taggart, P. Ochoa Espejo, \& P. Ostiguy (Eds.), The Oxford handbook of populism (pp. 48-72). Oxford and New York, NY: Oxford University Press.

Worsley, P. (1993). Populism. In J. Krieger (Ed.), The Oxford companion to politics of the world (pp. 730-731). New York, NY and Oxford: Oxford University Press.

Zulianello, M. (2020). Varieties of populist parties and party systems in Europe: From state-of-the-art to the application of a novel classification scheme to 66 parties in 33 countries. Government and Opposition, 55(2), 1-21.

\section{About the Authors}

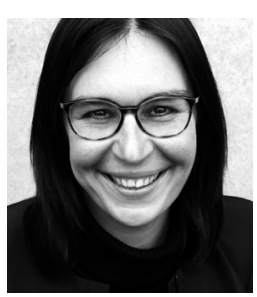

Marion Reiser is Professor of Political Science at the University of Jena (Germany) and holds a PhD (University of Goettingen) and a Habilitation (University of Frankfurt) in Political Science. Previously she was Professor at the University of Lüneburg and held postdoctoral positions at the Universities of Frankfurt, Hamburg, and Halle (Saale), and has been Visiting Fellow at the universities of Copenhagen, Birmingham, and Oslo. Her research interests cover political parties, elites, representation, and subnational politics.

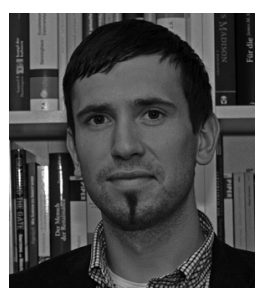

Jörg Hebenstreit is a Postdoctoral Researcher at the Department of Political Science at the University of Jena (Germany) and holds a PhD (University of Jena) in Political Science. His doctoral thesis dealt with the issue of campaign finance in the United States and its influence on the outcome of elections as well as the overall political system. Among his further research interests are non-majoritarian and technocratic institutions, responsiveness, and political inequality. 